\title{
ARE AFRICAN UNIVERSITIES CENTRES OF EXCELLENCE? THE CONSUMER PERSPECTIVE OF UGANDAN UNIVERSITIES
}

\author{
By Dr. E.s. Kasenene
}

\section{Abstract}

Universities the world over, strive to be centres of excellence, notwithstanding the differences in the scope of their educational fields. Universities in Africa, particularly those in Uganda, are not exceptional. However, whether those in Uganda have attained this end or not, is still questionable. Accordingly, this article employs a consumer perspective of educational excellence to establish the extent to which Ugandan universities have achieved this goal. The article is based on perceptions of 355 students selected from three private and two public universities in Uganda. The perceptions are analysed using ANOVA and factor analysis methods of SPSS. Results show that from the consumer perspective, universities in Uganda are at significantly different levels of excellence. While some are promising to fully become centres of excellence, others are still far below students' expectations as far delivering educational services as concerned; yet the position of other universities is still uncertain, particularly in terms of information services needed by students to research, enrich knowledge, and develop their talents and skills as desired; offering educational programmes or courses that help students to develop skills needed to be competent at work after training; and professional approach to the delivery of the services Put in place all information services needed by students to research, enrich knowledge, and develop their talents and skills as desired. The article is therefore concluded by noting that Ugandan universities need to strengthen the reliability, assurance and responsive of their educational services to the extent to which their enrolled students perceive them as centres of excellence. Accordingly, it is recommended that these universities should put offer educational programmes and information services needed by enrolled students and deliver them in a way that is professionally desired by students.

\section{Introduction}

Public and private universities the world over, tend to differ in their selected fields of knowledge impartation, skill and talent development, and in their specialised areas of research and development (Scott, 2004; Malick and Grisay, 2000). Some universities' didactic scope may cover only arts, social sciences, humanities, or science and technology, while that of others may focus on any two, three or all of these disciplines (Mutula, 2002). Whatever the discrepancies in their educational coverage, all universities strive to be centres of excellence (Boldt, 1991). This is well stated in the mission statements of almost all universities, the differences in diction used to articulate it notwithstanding (Boldt, 1991; Musaazi, 2005). Universities in Africa, particularly those in Uganda, are not exceptional.

The internet perusal of the mission statements of most African universities reveals that such universities as Cairo University in Egypt, University of Cape Town in South Africa, Nairobi University in Kenya, Dar Es Salaam University in Tanzania, University of Lagos in Nigeria, and others, struggle to be centres of academic and co-curricula 
excellence. In Uganda, the mission statements of Makerere University, Kyambogo University, Mbarara University of Science and Technology, Kampala International University, Ndejje University, Uganda Martyrs University Nkozi, Uganda Christian University Mukono, Busitema University, and others, indicate directly or indirectly that all these universities aspire to be centres of quality education (Kasozi, 2003; Lejeune, 2006). However, the extent to which these institutions have achieved this end is still debatable. Questions regarding whether the universities are really centres of excellence or not, have continually been posed but have not been exhaustively answered. Accordingly, this article is intended to make a contribution towards answering this question.

The article examines the extent to which Ugandan universities are centres of excellence. It uses a quantitative approach to explore and analyse the perceptions of students on whether their respective universities are centres of excellence or not. The criteria used to establish how far a university is a centre of excellence are derived from the literature reviewed henceforth.

\section{Review of Relevant Literature}

The Concise Oxford Dictionary (COD9) on CD-ROM defines excellence as a "state of excelling; surpassing merit or quality". This dictionary delineates excelling as "being superior, pre-eminent or the most outstanding in some quality" and 'to excel' as "surpassing one's previous performance". The definitions suggest that 'excellence' and 'excelling' refer to the endmost outcome that a person or an institution can attain in terms of quality or merit. That of 'excel' implies performing better in comparison to the performance achieved before. These definitions imply that to be centres of excellence, universities have to continually improve the services that they provide to their enrolled students and societies in general. This is tantamount to universities struggling to be providers of ever better quality of educational and research services (Ching-Yaw, Phyra and Keomony, 2007).

The quality of educational services can be determined by drawing upon the manner in which the general concept of service quality is measured (Tam Wai-Ming, 2008). Broadly speaking, service quality is determined using either the consumer perspective or the service provider's perspective (Bitner, Booms and Tetreault, 2002). According to Gronroos cited in Manyindo (2008: 34), the consumer perspective measures service quality in terms of the judgment made by service consumers through an evaluation process involving the consumers comparing their expectations of the service with the actual service delivered to them. Gronroos noted that the judgment is often expressed as a consumer perception of the actual service vis-à-vis the held expectation. The service provider's perspective determines service quality as the conformance of a service to the requirements or criteria set by the providers (Manyindo, 2008). This article adopts the consumers' perspective to establish how far Ugandan universities are centres of excellence as far as the services that they offer are concerned.

The specific measures used in the article are adopted from the scholarly work of Zeithaml, Parasuraman and Berry (2004), which views the concept of service quality as constituting the following dimensions: reliability, responsiveness, and assurance of a service. Zeithaml et al. (2004) conceived reliability of a service as the ability of a service provider to deliver the promised service dependably and accurately. According to 
Waithanji-Ngware and Ndirangu (2005), such reliability can be measured by establishing whether or not a service provider has in place all the material and human resources necessary to provide the promised services in an unfailing manner. Thus, service providers have to ensure that the available resources are so adequate as to give service consumers that confidence and certainty that a service is delivered as promised and in a consistent and responsible way (Mutula, 2002).

Zeithaml et al. (2004) considered the responsiveness of a service as the willingness of service providers to promptly provide services that match accurately with expressed consumer expectations. It is the ability to deliver services as desired by consumers and to deal effectively with any consumer complaints (Lenz, 1998). Consumers expect service providers to be always prepared to meet their requests (Ching-Yaw, Phyra and Keomony, 2007). Although consumers may acknowledge that errors and problems can occasionally occur, service providers are expected to respond to consumers' needs, complaints, and requests in a constructive and responsible manner (Ghobadian, Speller and Jones, 2005). Bitner, Booms and Tetreault (2002) viewed service assurance as the knowledge, courtesy and ability of a service provider to inspire trust and confidence in consumers that they can get the services whenever they need them.

\section{Educational Service Quality}

Essentially, the quality of university educational services can be established using the general dimensions of service quality: service reliability, responsiveness and assurance. Following the fore-cited literature and as Kayongo (2007) observed, the reliability of a university's educational services can be determined by establishing whether the university has the physical and human educational capacity necessary to support the provision of the promised academic and co-curricula services. The contention of this article is that if such capacity is perceived to be in place, it indicates that the university concerned is a centre of excellence as far as the reliability of the educational services it delivers is concerned and vice-versa. A university is also considered to be a promising centre of excellence if it is in the process of building this capacity.

Educational capacity of any university may be gauged in accordance with technical criteria set by the concerned assurance body established by the Ministry of Education (Getler and Glewwe, 2002). In Uganda, this body is referred to as the National Council for Higher Education (Kayongo, 2007). This capacity can also be determined using the perceptions of students who consume the services (Ching-Yaw, Phyra and Keomony, 2007). Students' perceptions are used in this article because they indicate an evaluation of service quality in terms of value judgments held by the consumers of the educational services. They therefore reveal the extent to which a university's educational capacity is able to support the delivery of services as promised and as dependably and accurately as expected. The perceptions are held on both academic and the non-academic capacity (Gerhard and Gördel, 2006).

The perceptions on academic capacity are expressed on whether or not the available academic physical buildings such as lecture rooms, laboratories and libraries are specious enough to instil confidence in students that the associated services can be provided as promised and in a consistent manner (Gerhard and Gördel, 2006; Getler \& Glewwe, 2002; Munroe-Blum, 2004). The perceptions are also held on the dependability of the 
provided library services, materials and equipment such as textbooks and reference materials, equipment and facilities such as computers, as well as on the available laboratory equipment and chemicals used to deliver services to students (Tam Wai-Ming, 2008). Other perceptions are held on the adequacy of the teaching staff (professors, senior lecturers, junior lecturers and teaching assistants) in comparison to the number of enrolled students while others are held on the extent to which a university promotes research and publication as well as innovation and development (Geli de Ciurana and Filho, 2006; Gibson and Cohen, 2003; Goodhew, 2007). Regarding non-academic capacity, consumer perceptions are expressed on the recreational, sports and upkeep facilities, as well as equipment and materials made available to facilitate the delivery of services that support the development of students' non-academic talents and skills (Kayongo, 2007).

On the basis of Bitner et al's (2002) conception of service assurance, that of educational services can be established by ascertaining the perceived level of knowledge, courtesy and ability of a university's employees to inspire trust and confidence in students that they (the students) can access the provided services whenever they need them. Establishing such assurance necessitates finding out the perceived regularity of lecturers in teaching, their commitment and demonstration of professionalism and knowledge of taught subjects (Gerhart, 2006; Sánchez and Elena, 2006).

Regarding the responsiveness of educational services, emphasis has to be placed on establishing perceptions on whether or not the services meet students' academic and nonacademic expectations and needs (Kayongo, 2007; Tam Wai-Ming, 2008). In higher education, student educational expectations and needs include: gaining knowledge and skills required to be competently productive, employability, and career growth through development of their talents (Fepuleai, 2007; Malick and Grisay, 2000). In short, only when universities are able to provide promised services in a way that assures and responds to students' educational needs such as gaining skills and knowledge, talent development, and productivity, can they claim to be centres of excellence.

In general, literature indicates that for any university to be a centre of excellence, it has to have the capacity to deliver educational services that should be perceived as reliable, assuring and responsive to the educational expectations and needs of its enrolled students. These are therefore the principal indicators that formed the criteria that were used to investigate and establish the extent to which Uganda's universities are centres of excellence. The investigation was carried out using the methodology described in the next section.

\section{Methodology}

This article was put together basing on perceptions collected using a structured questionnaire administered to a sample of 355 students selected from five universities. Both the students and the universities were selected using simple random sampling. This sampling technique was used because each university and each student had an equal chance of being selected to take part in the study. Regarding universities, a list of private universities and another of public universities of Uganda were compiled. While two universities were selected from the public universities' list, three universities selected from the private universities' list without replacement. The selection of students from each 
of the selected universities involved finding any student in a lecture room, library, or resting place at a university's campus and requesting them to take part in the study. The request involved self-introduction and soliciting students' cooperation by explaining the objective of the study. Any student who accepted was selected to fill in the questionnaire. Students' perception of the reliability, responsiveness and assurance of the educational services delivered at the selected universities was established using a five-point Likert scale of responses running from strongly agree, through agree, not sure, disagree, to strongly disagree. The responses were scaled from 5, 4, 3, 2, downwards to 1 respectively. The collected perceptions were analysed using confirmatory factor analysis and Analysis of Variance (ANOVA) methods. ANOVA was used to establish whether there were significant differences in the perceived excellence of the universities. Confirmatory factor analysis helped to extract and identify the principal indicators of educational 94 service quality and to confirm whether the indicators were reliable measures of selected universities as centres of excellence.

\section{Findings}

When the close-ended responses given by selected students to the questionnaire items administered to establish the perceived quality of educational services delivered by Ugandan universities were factor analysed, results obtained are summarised in Table 1.

Table 1: Factor Analysis Results on Students' Perception of the Level of Excellence at the Selected Universities in Uganda

\begin{tabular}{|c|c|c|c|}
\hline \multirow[b]{2}{*}{ Questionnaire Items } & \multicolumn{3}{|c|}{ Principal Indicators } \\
\hline & 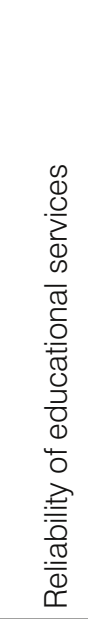 & 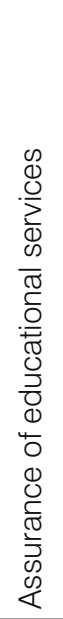 & 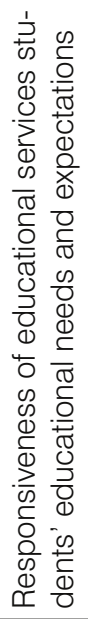 \\
\hline $\begin{array}{l}\text { Information services that students need to } \\
\text { research, enrich knowledge, and develop their } \\
\text { talents and skills are in place }\end{array}$ & .912 & & \\
\hline $\begin{array}{l}\text { Library services and facilities needed by students } \\
\text { to learn a effectively as expected are provided }\end{array}$ & .867 & & \\
\hline
\end{tabular}




\begin{tabular}{|c|c|c|c|}
\hline $\begin{array}{l}\text { Laboratory equipment/materials needed by stu- } \\
\text { dents to effectively learn }\end{array}$ & .829 & & \\
\hline $\begin{array}{l}\text { Services provided to students by the university's } \\
\text { staff are dependable }\end{array}$ & .779 & & \\
\hline $\begin{array}{l}\text { Students entitled to feeding at the university are } \\
\text { provided with the desired balanced diet }\end{array}$ & .754 & & \\
\hline $\begin{array}{l}\text { Students entitled to accommodation are provided } \\
\text { with the desired accommodation services }\end{array}$ & .703 & & \\
\hline $\begin{array}{l}\text { The academic services provided at the university } \\
\text { are updated regularly }\end{array}$ & 687 & & \\
\hline $\begin{array}{l}\text { The university promotes research by sponsoring } \\
\text { undertaken research work }\end{array}$ & 676 & & \\
\hline $\begin{array}{l}\text { Recreational facilities needed by students to de- } \\
\text { velop their sports talents are provided }\end{array}$ & .614 & & \\
\hline $\begin{array}{l}\text { The information provided to students by the } \\
\text { university's employees is accurate }\end{array}$ & .602 & & \\
\hline $\begin{array}{l}\text { Employees provide educational services to stu- } \\
\text { dents in a timely manner. }\end{array}$ & .583 & & \\
\hline $\begin{array}{l}\text { The University's employees have the ability to } \\
\text { perform services dependably. }\end{array}$ & .573 & & \\
\hline $\begin{array}{l}\text { University's employees demonstrate professional- } \\
\text { ism when delivering educational services }\end{array}$ & & .845 & \\
\hline $\begin{array}{l}\text { University employees are more interested in per- } \\
\text { sonal benefits than serving students }\end{array}$ & & .791 & \\
\hline $\begin{array}{l}\text { The University promptly solve complaints raised by } \\
\text { students about the delivered services }\end{array}$ & & .753 & \\
\hline $\begin{array}{l}\text { The university's employees are efficient in their ef- } \\
\text { forts to serve students }\end{array}$ & & .732 & \\
\hline $\begin{array}{l}\text { University's employees are sufficiently knowledge- } \\
\text { able in the services delivered to students. }\end{array}$ & & .712 & \\
\hline $\begin{array}{l}\text { The University's lecturers teach students without } \\
\text { dodging any lecture }\end{array}$ & & .677 & \\
\hline $\begin{array}{l}\text { Employees provide educational services to stu- } \\
\text { dents with commitment. }\end{array}$ & & .557 & \\
\hline $\begin{array}{l}\text { The University's employees are all competent in } \\
\text { their efforts to serve students }\end{array}$ & & .523 & \\
\hline $\begin{array}{l}\text { The educational programmes or courses offered } \\
\text { by the university help students to develop skills } \\
\text { needed to be competent at work after training }\end{array}$ & & & .871 \\
\hline $\begin{array}{l}\text { The academic courses offered by the university } \\
\text { encourage the employability of the students }\end{array}$ & & & .857 \\
\hline
\end{tabular}




\begin{tabular}{|c|c|c|c|}
\hline $\begin{array}{l}\text { The educational programmes offered by the uni- } \\
\text { versity provide knowledge needed by students to } \\
\text { satisfy their educational needs }\end{array}$ & & & .677 \\
\hline $\begin{array}{l}\text { University provides non-academic services that } \\
\text { help students to develop their non-academic } \\
\text { talents }\end{array}$ & & & .566 \\
\hline $\begin{array}{l}\text { The academic programmes offered by the univer- } \\
\text { sity are able to transform students into productive } \\
\text { citizens }\end{array}$ & & & .509 \\
\hline Alpha & .807 & .712 & .698 \\
\hline$\%$ Variance explained & 59.948 & 13.843 & 8.785 \\
\hline \% Cumulative Variance Explained & & 73.791 & 82.576 \\
\hline
\end{tabular}

Extraction Method: Principal Component Analysis. Rotation Method: Varimax with Kaiser Normalization Findings in Table 1 indicate that extracted from the responses were three principal indicators of the level of excellence at the selected universities. These were identified as: reliability and assurance of educational services, and these services' responsiveness to students' educational needs. The total cumulative percentage of variance indicates that all these indicators explained up to $82.576 \%$ of the variation in the level of this excellence. The Alpha values in Table 1 show the reliability of the indicators in explaining the level of the universities as centres of excellence of. If the Alpha value is greater than 0.5 , it indicates that the corresponding indicator is reliable in explaining the level universities' excellence. The percentage of variance indicates how each indicator accounts for variation in this level (Kothari, 2005). Accordingly, since all Alpha values in Table 1 were greater than 0.5 , they indicate that all the extracted principal indicators were reliable in explaining the level of excellence at the selected universities. The reliability of the provided educational services was the most dependable indicator that also explained the largest variation in this level (Alpha $=0.807$, Variance $=59.948 \%)$. It was followed by the assurance of the educational services (Alpha $=0.712$, Variance $=13.843 \%)$. The responsiveness of provided educational services to students' educational needs and expectations was the least reliable indicator $($ Alpha $=0.698$, Variance $=8.785 \%)$.

The values at the intersection between the questionnaire items shown in Table 1 and the principal indicators extracted from these items are called factor loadings. They show how respondents perceived the items as measures of the extracted indicators. From this explanation, factor loadings in Table 1 indicate that to most of the respondents, having in place information services that students need to research, enrich knowledge, and develop their talents and skills was the best measure of the reliability of educational services offered by a university (Factor Loading $=0.912$ ). Similarly, most respondents showed that a university employees' demonstration of professionalism when delivering educational services was the best measure of the assurance of educational services (Factor Loading $=0.845$ ). In the same way, the best indicator of the responsiveness of educational services to students' educational needs and expectations constituted offering educational programmes that help students develop skills needed to be competent at 
work after training (Factor Loading $=0.871)$.

In general, findings in Table 1 indicate that most of the students perceive a university as a centre of excellence if:

(a) The reliability of the university's educational services is pursued by putting in place information services needed by students to research, enrich knowledge, and develop their talents and skills;

(b) The assurance of the educational services offered by the university is maintained through emphasizing a professional approach to the delivery of the services;

(c) The responsiveness of educational services to students' educational needs is guaranteed by ensuring that offered educational programmes or courses help students to develop skills needed to be competent at work after training

In addition, ANOVA was carried out to establish how the foregoing principal and specific indicators of excellence were perceivably accentuated at the selected universities. Results obtained are shown in Table 2. 
Makerere Journal of Higher Education (MAJOHE) Vol. 2, 2009

\begin{tabular}{|c|c|c|c|c|c|c|c|c|c|c|c|}
\hline & $\ddot{\infty}$ & 8 & 8 & 8 & 8 & 8 & 8 & 8 & 8 & 8 & 8 \\
\hline & $\frac{\stackrel{0}{\vec{N}}}{\frac{\mathbb{N}}{\overrightarrow{1}}}$ & 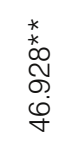 & 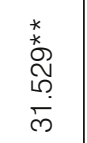 & $\begin{array}{l}\stackrel{*}{*} \\
\stackrel{*}{5} \\
\ddot{\infty} \\
\tilde{0}\end{array}$ & 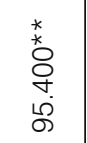 & $\begin{array}{l}* \\
* \\
\infty \\
\infty \\
\infty \\
\infty \\
\infty\end{array}$ & $\begin{array}{l}* \\
* \\
\infty \\
\simeq 1 \\
0 \\
\dot{0} \\
\stackrel{0}{0}\end{array}$ & $\begin{array}{l}* \\
* \\
\stackrel{*}{\circ} \\
\stackrel{R}{*} \\
\dot{f}\end{array}$ & 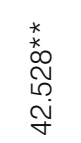 & 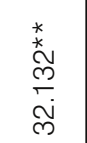 & 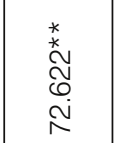 \\
\hline & $\frac{\pi}{0}$ & $\nabla$ & $\nabla$ & $\nabla$ & 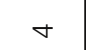 & $\nabla$ & $\nabla$ & $\nabla$ & 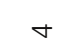 & 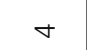 & $\nabla$ \\
\hline \multirow{6}{*}{ 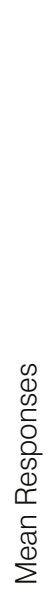 } & $\varsigma \subseteq \mathcal{E}=\mathrm{N}$ & $\begin{array}{l}\hat{O} \\
\dot{m}\end{array}$ & 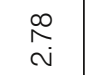 & $\begin{array}{l}\text { ले } \\
\text { i }\end{array}$ & $\underset{\substack{\tau \\
\sim}}{ }$ & $\begin{array}{l}\stackrel{e}{N} \\
\stackrel{\sim}{N}\end{array}$ & 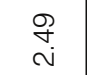 & $\underset{\sim}{\stackrel{f}{v}}$ & 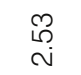 & $\stackrel{\stackrel{P}{\sim}}{\sim}$ & 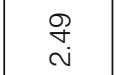 \\
\hline & $\begin{array}{r}t 9=u \\
9 \cap\end{array}$ & $\stackrel{\hat{N}}{n}$ & $\stackrel{\infty}{\stackrel{\infty}{\infty}}$ & ले & $\begin{array}{l}\hat{N} \\
\text { ñ }\end{array}$ & $\underset{\oplus}{\check{m}}$ & مִ & $\stackrel{\stackrel{\sim}{N}}{m}$ & $\stackrel{\infty}{\stackrel{\infty}{\infty}}$ & S & $\stackrel{\text { N }}{m}$ \\
\hline & $\begin{array}{r}29=u \\
t \cap\end{array}$ & $\stackrel{\infty}{\stackrel{\infty}{\infty}}$ & $\begin{array}{l}\stackrel{0}{N} \\
\dot{m}\end{array}$ & $\hat{m}$ & 禹 & $\begin{array}{l}\infty \\
\stackrel{\infty}{\infty} \\
\infty \\
\infty\end{array}$ & مִ & 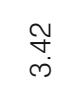 & fे. & $\stackrel{\circ}{+}$ & 冓 \\
\hline & $\begin{array}{r}\varepsilon L=u \\
\varepsilon \cap\end{array}$ & $\begin{array}{l}\hat{0} \\
\dot{m}\end{array}$ & חై & $\begin{array}{l}\infty \\
\stackrel{\infty}{\infty} \\
\text {. }\end{array}$ & $\begin{array}{l}\stackrel{2}{\circ} \\
\text { ले }\end{array}$ & $\begin{array}{l}\infty \\
\infty \\
\infty \\
\end{array}$ & Бे & $\begin{array}{l}\infty \\
\infty \\
m\end{array}$ & $\stackrel{\text { Pे }}{\text { ले }}$ & م & $\bar{i}$ \\
\hline & $\begin{array}{r}\angle 9=u \\
z \cap\end{array}$ & $\stackrel{\circ}{\frac{0}{r}}$ & $\begin{array}{l}\infty \\
\stackrel{\infty}{N} \\
\sim\end{array}$ & $\stackrel{?}{r}$ & $\stackrel{\text { o }}{\leftarrow}$ & O̊ & $\hat{\stackrel{N}{N}}$ & 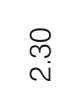 & 음 & $\stackrel{\text { Oִ }}{\leftarrow}$ & $\stackrel{\text { Oִ }}{\leftarrow}$ \\
\hline & $\begin{array}{r}68=u \\
1 \cap\end{array}$ & $\underset{N}{N}$ & $\frac{\circ}{i}$ & ळे & 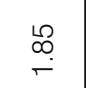 & $\stackrel{?}{\stackrel{R}{r}}$ & 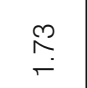 & ò & $\stackrel{\substack{\infty \\
\infty}}{\infty}$ & $\stackrel{\infty}{\stackrel{\infty}{\sim}}$ & $\begin{array}{l}\text { o } \\
\text { ì }\end{array}$ \\
\hline & $\stackrel{\times}{\frac{\pi}{2}}$ & $\nabla$ & $\nabla$ & $\nabla$ & $\nabla$ & $\nabla$ & $\nabla$ & $\nabla$ & $\nabla$ & $\nabla$ & $\nabla$ \\
\hline & $\stackrel{5}{\Sigma}$ & $\tau$ & - & - & \ulcorner & - & - & - & - & - & - \\
\hline & 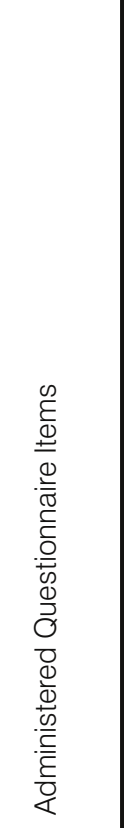 & 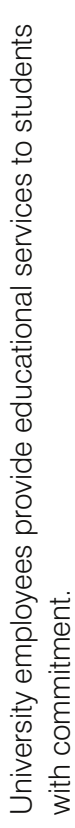 & 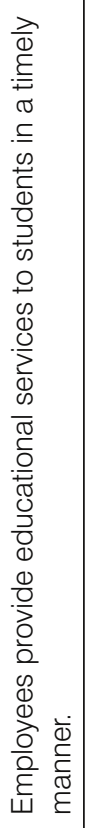 & 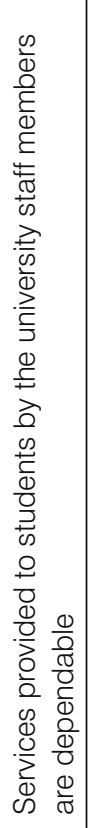 & 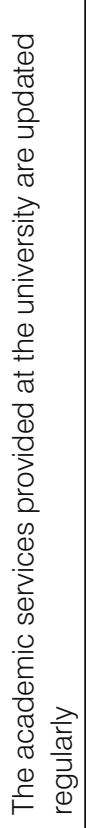 & 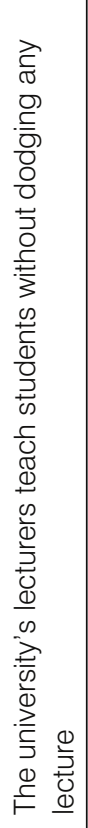 & 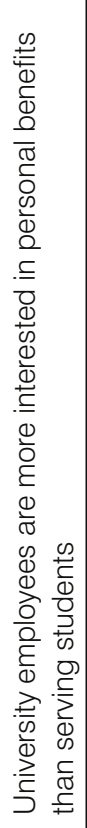 & 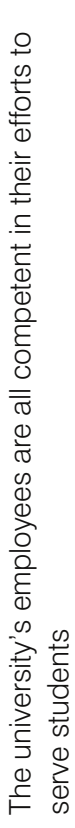 & 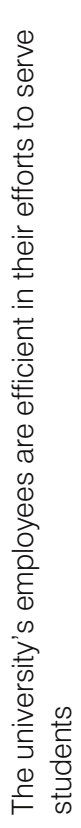 & 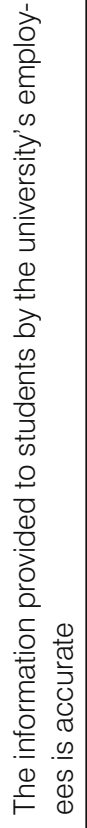 & 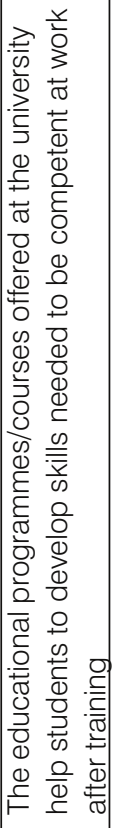 \\
\hline
\end{tabular}




\begin{tabular}{|c|c|c|c|c|c|c|c|c|c|c|c|c|c|}
\hline 8 & 8 & 8 & ৪ & 8 & ৪ & 8 & 8 & ৪ & 8 & 8 & 8 & 8 & 8 \\
\hline 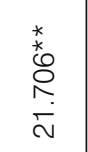 & 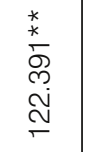 & 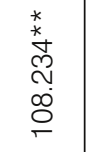 & $\begin{array}{l}* \\
* \\
\stackrel{2}{*} \\
\stackrel{0}{\infty} \\
\infty \\
\infty\end{array}$ & 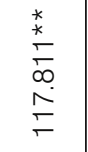 & 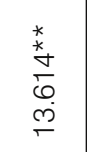 & 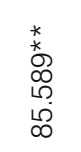 & $\begin{array}{l}* \\
* \\
* \\
\infty \\
0 \\
0 \\
0 \\
8\end{array}$ & 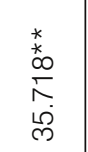 & 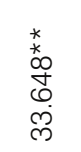 & $\begin{array}{l}\stackrel{*}{*} \\
\frac{*}{5} \\
\stackrel{\infty}{\sigma}\end{array}$ & 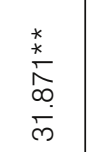 & 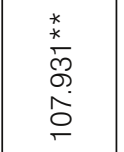 & 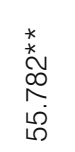 \\
\hline ナ & $\nabla$ & $\nabla$ & $\nabla$ & $\nabla$ & $\nabla$ & $\nabla$ & $\nabla$ & & $\nabla$ & $\nabla$ & $\nabla$ & $\nabla$ & ナ \\
\hline$\frac{m}{m}$ & $\stackrel{\substack{\sim \\
\sim}}{\sim}$ & $\begin{array}{l}\widetilde{N} \\
\sim \\
\sim \\
\sim\end{array}$ & 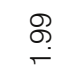 & $\stackrel{\text { లి }}{\stackrel{\sim}{\sim}}$ & $\begin{array}{l}\widehat{\infty} \\
\sim \\
\sim\end{array}$ & $\begin{array}{l}\infty \\
\stackrel{\infty}{\sim} \\
\sim \\
\sim\end{array}$ & \begin{tabular}{l}
\multirow{0}{0}{} \\
$\sim$ \\
$\sim$
\end{tabular} & 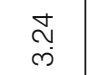 & $\begin{array}{l}\stackrel{\leftrightarrow}{\sim} \\
\stackrel{\sim}{N}\end{array}$ & $\begin{array}{l}\hat{L} \\
\sim \\
\sim\end{array}$ & $\frac{m}{m}$ & $\begin{array}{l}\infty \\
\stackrel{\infty}{\rho} \\
\sim \\
\sim\end{array}$ & 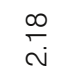 \\
\hline $\begin{array}{l}\mathscr{Q} \\
\dot{m}\end{array}$ & 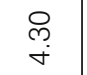 & 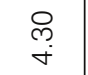 & 市 & 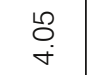 & 市 & $\stackrel{0}{\stackrel{\sigma}{\sigma}}$ & $\underset{+}{\stackrel{\circ}{\circ}}$ & $\begin{array}{l}\text { mे } \\
\text { + }\end{array}$ & $\frac{\infty}{\frac{\infty}{\infty}}$ & $\begin{array}{l}\infty \\
\infty \\
m\end{array}$ & $\stackrel{\stackrel{\sim}{\sim}}{\stackrel{\sim}{*}}$ & $\begin{array}{l}\mathscr{D} \\
\infty \\
\text { m. }\end{array}$ & $\dot{m}$ \\
\hline $\begin{array}{l}\stackrel{M}{N} \\
m\end{array}$ & $\begin{array}{l}\stackrel{P}{+} \\
\text { m. }\end{array}$ & 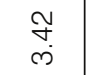 & $\begin{array}{l}\text { fे. } \\
\text { ले }\end{array}$ & $\begin{array}{l}\widetilde{m} \\
\ddot{m}\end{array}$ & $\begin{array}{l}\infty \\
0 \\
\ddot{\infty}\end{array}$ & $\begin{array}{l}\mathscr{Q} \\
\stackrel{\infty}{ }\end{array}$ & $\begin{array}{l}\widetilde{N} \\
\tilde{N}\end{array}$ & $\begin{array}{l}\stackrel{N}{\sim} \\
\stackrel{\sigma}{*}\end{array}$ & $\hat{m}$ & $\underset{\sim}{\hat{N}}$ & $\begin{array}{l}\widetilde{N} \\
\stackrel{N}{\infty}\end{array}$ & $\begin{array}{l}\text { @) } \\
\text { ल) }\end{array}$ & 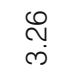 \\
\hline$\underset{\Gamma}{\bar{\rho}}$ & $\underset{-}{8}$ & $\frac{\bar{\sigma}}{i}$ & $\begin{array}{l}0 \\
\text { m. } \\
\text { ले }\end{array}$ & $\begin{array}{l}\text { R } \\
\stackrel{M}{1}\end{array}$ & $\begin{array}{l}\infty \\
\text { O } \\
\text { ले }\end{array}$ & $\begin{array}{l}\infty \\
\stackrel{\infty}{+} \\
\text { ले }\end{array}$ & $\begin{array}{l}\bullet \\
\stackrel{1}{ } \\
\oplus\end{array}$ & $\begin{array}{l}\underset{\tau}{\check{\sigma}} \\
\text { ल. }\end{array}$ & $\begin{array}{l}R \\
\stackrel{R}{M}\end{array}$ & $\begin{array}{l}\infty \\
\infty \\
\infty \\
\infty\end{array}$ & $\begin{array}{l}\text { p) } \\
\text { N }\end{array}$ & $\begin{array}{l}\stackrel{f}{+} \\
\stackrel{\infty}{\infty}\end{array}$ & $\stackrel{\circ}{\mathrm{N}}$ \\
\hline $\begin{array}{l}\underset{N}{N} \\
\text { N }\end{array}$ & $\stackrel{ㅇ ㅗ ㅇ ~}{\leftarrow}$ & $\begin{array}{l}\stackrel{\sim}{N} \\
\stackrel{N}{N}\end{array}$ & $\stackrel{\text { L }}{\leftarrow}$ & $\begin{array}{l}\infty \\
\infty \\
\sim\end{array}$ & \begin{tabular}{l}
\multirow{\sigma}{}{} \\
$\stackrel{\sim}{ }$
\end{tabular} & $\begin{array}{l}\underset{N}{N} \\
\underset{N}{ }\end{array}$ & $\frac{\sigma}{i}$ & $\begin{array}{l}\mathscr{} \\
\stackrel{\sim}{N}\end{array}$ & $\frac{\bullet}{\sim}$ & $\begin{array}{l}\underset{\sim}{O} \\
\text { d }\end{array}$ & $\begin{array}{l}\hat{\omega} \\
\dot{M}\end{array}$ & $\stackrel{\text { P }}{\leftarrow}$ & - \\
\hline 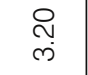 & $\frac{\circ}{\stackrel{ }{i}}$ & $\stackrel{\text { Ḷ }}{\leftarrow}$ & $\stackrel{\oplus}{\stackrel{p}{\leftarrow}}$ & 萬 & $\begin{array}{c}\text { N } \\
\underset{\sim}{N}\end{array}$ & $\underset{\stackrel{ }{+}}{\stackrel{\text { - }}{-}}$ & 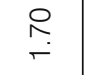 & $\begin{array}{l}\text { D } \\
\text { N }\end{array}$ & $\underset{\substack{\infty \\
\hdashline}}{\stackrel{0}{0}}$ & $\begin{array}{l}\infty \\
\stackrel{\infty}{\sim} \\
\stackrel{\sim}{*}\end{array}$ & $\begin{array}{l}\stackrel{\bullet}{\llcorner} \\
\stackrel{\sim}{\sim}\end{array}$ & 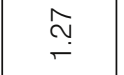 & $\stackrel{8}{\stackrel{\leftrightarrow}{-}}$ \\
\hline$\nabla$ & ما & مـا & $\checkmark$ & ما & $\nabla$ & ما & ما & ما & $\nabla$ & $\nabla$ & ما & $\nabla$ & 寸 \\
\hline- & - & \ulcorner & $r$ & - & $\tau$ & - & $\tau$ & - & $\tau$ & - & $\tau$ & $\Gamma$ & \\
\hline 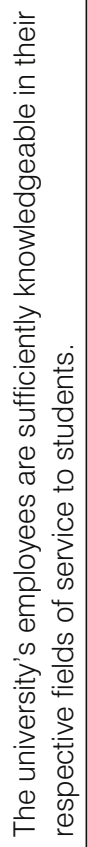 & 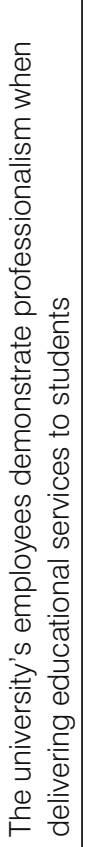 & 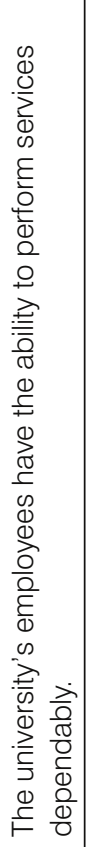 & 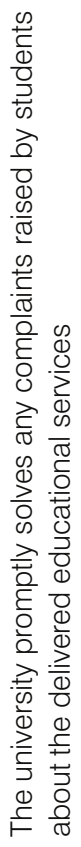 & 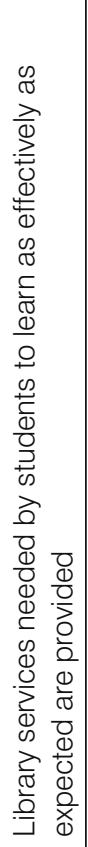 & 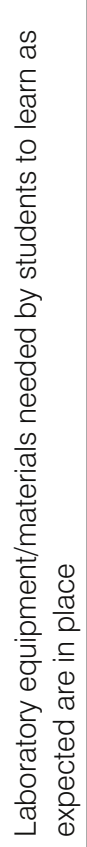 & 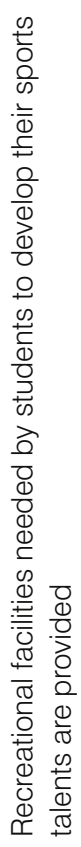 & 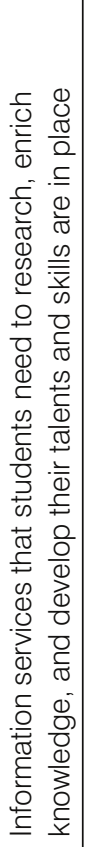 & 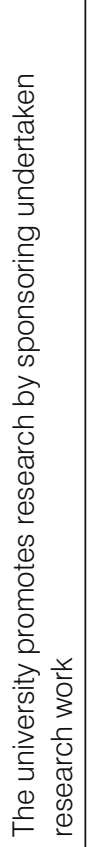 & 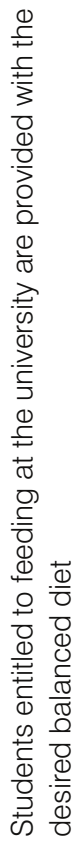 & 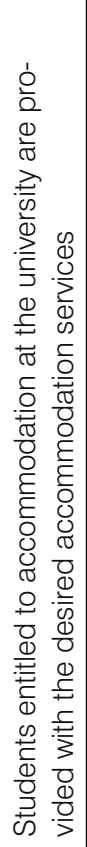 & 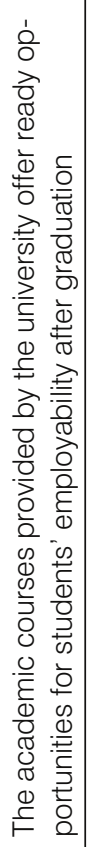 & 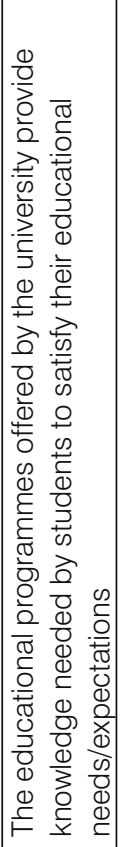 & 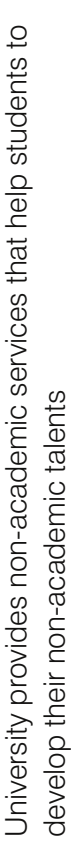 \\
\hline
\end{tabular}




\begin{tabular}{|c|c|c|c|c|c|}
\hline & ৪ & ৪ & 8 & ৪ & 8 \\
\hline & 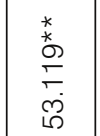 & 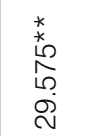 & 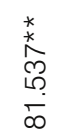 & $\begin{array}{l}x^{*} \\
\overbrace{}^{*} \\
\hat{D}^{2} \\
\infty \\
\infty \\
\infty\end{array}$ & \begin{tabular}{l}
$*$ \\
$*$ \\
\multirow{0}{*}{} \\
$\infty$ \\
$\infty$ \\
$\stackrel{N}{N}$
\end{tabular} \\
\hline & ナ & $\checkmark$ & $\nabla$ & $\nabla$ & $\nabla$ \\
\hline & $\begin{array}{l}\underset{N}{N} \\
\text { N }\end{array}$ & $\underset{\stackrel{\sim}{\sim}}{\stackrel{\sim}{\sim}}$ & $\begin{array}{l}\stackrel{2}{2} \\
\stackrel{\sim}{\sim}\end{array}$ & $\frac{\sim}{\stackrel{\sim}{N}}$ & $\begin{array}{l}\stackrel{L}{\rho} \\
\stackrel{n}{n}\end{array}$ \\
\hline 100 & $\begin{array}{l}\stackrel{\sim}{N} \\
\stackrel{n}{n}\end{array}$ & $\begin{array}{l}\text { Oె } \\
\text { i }\end{array}$ & $\begin{array}{l}\stackrel{8}{\circ} \\
\dot{+}\end{array}$ & $\begin{array}{l}\stackrel{\rho}{q} \\
\dot{m}\end{array}$ & $\begin{array}{l}\tilde{N} \\
\text { nె }\end{array}$ \\
\hline & $\begin{array}{l}\stackrel{P}{N} \\
\stackrel{\infty}{n}\end{array}$ & $\begin{array}{l}\text { లి } \\
\text { ले }\end{array}$ & $\underset{ }{\stackrel{ }{\forall}}$ & $\begin{array}{l}\text { 户े } \\
\text { d }\end{array}$ & $\begin{array}{l}0 \\
\stackrel{\infty}{\infty} \\
\stackrel{n}{2}\end{array}$ \\
\hline & $\begin{array}{l}\infty \\
\stackrel{\infty}{m}\end{array}$ & 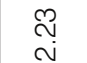 & $\begin{array}{l}\text { R } \\
M\end{array}$ & $\underset{F}{\digamma}$ & $\underset{\dot{N}}{\bar{m}}$ \\
\hline & ơ & $\stackrel{m}{\square}$ & $\stackrel{?}{r}$ & $\stackrel{N}{N}$ & g \\
\hline & 它 & $\stackrel{\infty}{\infty}$ & $\stackrel{\tau}{r}$ & $\stackrel{\llcorner}{\complement}$ & 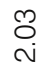 \\
\hline & 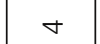 & $\nabla$ & ما & $\nabla$ & $\nabla$ \\
\hline & - & - & - & - & - \\
\hline & 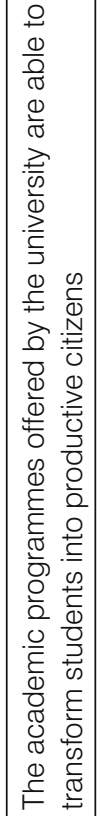 & 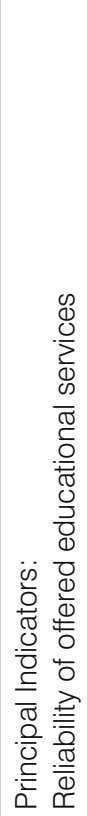 & 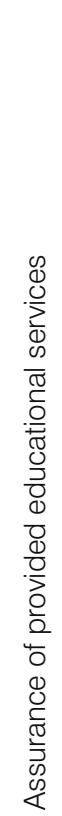 & 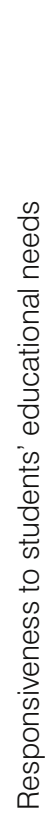 & 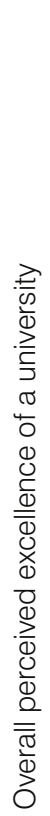 \\
\hline & & & & & \\
\hline
\end{tabular}

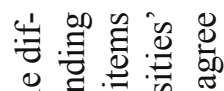

E

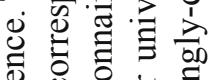

过

这造点艺

पै चु

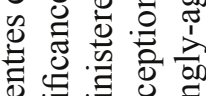

ป.

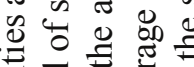

:

¿

.

$\exists \stackrel{0}{\square}$

를 흘

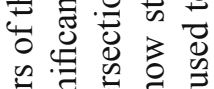

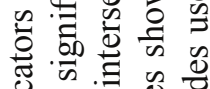

.

.

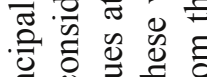

ठ응 을

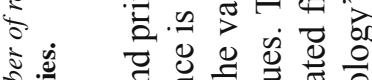

㻤 击 电氙 ग्ण

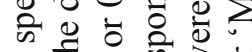

之े के

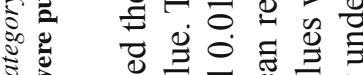

造

己

ह

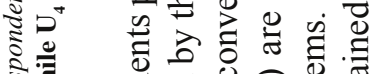

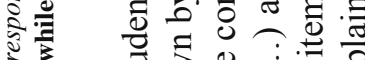

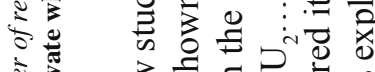

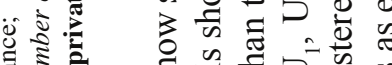

章苛

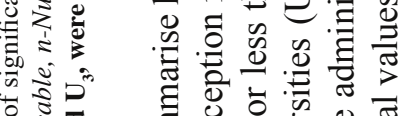

จ.

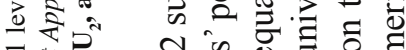
范

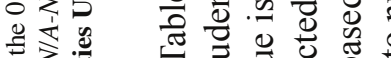

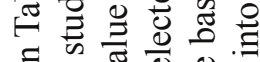

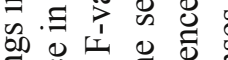

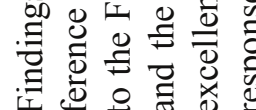


A mean value close to ' 1 ', represents 'Strongly Disagree' and one close to '2' stands for 'Disagree'. These two responses stand for a perception that a university is not a centre of excellence as far as the specific or principal indicators shown in Table 2 are concerned. The mean value close to ' 3 ' corresponds to 'Not sure', and points to students' uncertainty about the excellence of a university. The mean value close to '4' represents 'Agree'. It represents a perception that a university concerned is a promising centre of excellence. The mean value close to ' 5 ' corresponds to 'Strongly Agree'. It shows a perception that a university is a centre of excellence as far as a given indicator is concerned. It should be noted that the maximum or minimum value appearing as Max or Min in Table 2, respectively, could be any of the codes, depending on how respondents answered a particular item in the Table. If some respondents strongly disagreed, the minimum value is ' 1 '. If some respondents strongly agreed, the maximum is ' 5 '. If respondents varied between strongly agree and agree, then the maximum value is ' 4 '.

Based on the above interpretation, the F-values in Table 2 indicate that students' perception of all the specific and principal indicators of excellence significantly differed across the selected universities. This implies that students' perception of the overall excellence was significantly different across the universities (F-value $=28.864$, Sig. $<0.01)$. This implies that universities in Uganda were perceivably at significantly different levels of excellence. Generally, a critical look at the response pattern in Table 2 reveals the differences in the perceived levels of excellence more clearly. The pattern indicates that the mean value corresponding to the overall perceived excellence of university $U_{1}$ (Mean $=2.03$ ) was close to ' 2 ' while that corresponding to university $U_{2}($ Mean $=1.49)$ was close to ' 1 '. This implies that although these two universities were both not perceived as centres of excellence, one of them was worse than the other. The mean values corresponding to university $\mathrm{U}_{4}($ Mean $=3.56)$ and to university $\mathrm{U}_{5}($ Mean $=3.52)$ were close to ' 4 '. This indicates that these two universities were perceivably promising centres of excellence. The mean value $($ Mean $=2.71)$ corresponding to university $\mathrm{U}_{3}$ was close to ' 3 ', which means that students were uncertain about this university as a centre of excellence. The overall mean value of 3.55 shows that, on average, all students perceived Ugandan universities as promising centres of excellence. This effectively shows that none of the universities had reached a perceivably optimal level of excellence.

\section{Discussion of Findings}

Findings in Table 1 confirm that Zeithaml et al's (2004) measures of general service quality (reliability, assurance and responsiveness) as also dependable measures of students' perception of their universities as centres of excellence. In particular, the findings show that students perceive the reliability of a university's educational services largely in terms of availability of information services needed to carry out research, enrich knowledge, and develop talents and skills. This implies that a university qualifies to be a perceived centre of excellence if it amply provides such services to its enrolled students. Table 1 shows further that students perceive the assurance of the educational services offered by a university more in terms of the university's ability to pursue a professional approach to the delivery of the services. This suggests that a university is perceived as a centre of excellence if students view its delivery of educational services as professional. Furthermore, Table 1 indicates that students' perceive the responsiveness of educational services to their educational needs largely in terms of educational programmes and 
courses that help them to develop skills needed to be competent at work after training. This implies that students regard a university as a centre of excellence if it is able to offer educational programmes out of which students are able to develop needed work competencies.

Unfortunately, a critical scrutiny of the findings in Table 2 reveals that none of the universities offered information services, educational programmes and courses, and a professional approach to their delivery as expected by students. This implies that the quality of the educational services delivered by the universities fell short of fully meeting students' expectations. Indeed, students' average perception in Table 2 indicates that while two of the universities did not deliver educational services that satisfied their enrolled students, one university left its students uncertain of the services that it delivered to them. Only two of the selected universities were promising as far as delivering the 102 desired quality of these services was concerned, and even then, the fact that they were perceivably promising implies that they, too, had not fully reached the desired extent of excellence.

\section{Conclusion}

The consumer perspective of educational service quality reveals that as centres of excellence, universities in Uganda are perceivably at different levels. While some are promising to fully become centres of excellence, others are so behind that the quality of educational services delivered to their students is still unsatisfactory; yet the position of others is still uncertain. This effectively shows that none of the universities in Uganda has reached the extent to which it is perceived by its students as a satisfactory centre of excellence. The universities therefore need to strengthen their struggle in the pursuit of becoming centres of excellence to the extent expected by their students.

\section{Recommendations}

Universities in Uganda should strive to reach the extent to which their enrolled students perceive them as centres of excellence by building the reliability, assurance and responsiveness of their offered educational services. However, the effort needed by the universities differs. While those at the promising level need less effort, those that deliver educational services whose quality is perceivably uncertain or unsatisfactory need more effort. To achieve the expected excellence, the universities should:

1) Put in place all information services needed by students to research, enrich knowledge, and develop their talents and skills as desired

2) Emphasize a professional approach to the delivery of the services

3) Offer educational programmes or courses that help students to develop skills needed to be competent at work after training.

\section{REFERENCES}

Bitner, M. J., Booms, B. H., \& Tetreault, M. S. (2002). The Service Encounter: Diagnosing Favourable and Unfavourable Incidents, Journal of Marketing, 1, 54, 71-84.

Boldt, B. D. (1991). University Strategic Management: A Businessman's View, International Journal of Educational Management 5, 5, accessed on $12^{\text {th }}$ May 2008 at 
http://www.emeraldinsight.com

Ching-Yaw, C., Phyra, S. \& Keomony, S. (2007). Benchmarking potential factors leading to education quality: A study of Cambodian higher education Quality Assurance in Education, 2, 15, accessed on $12^{\text {th }}$ May 2008 at http:// www.emeraldinsight.com

Concise Oxford Dictionary (COD9) on CD-ROM, accessed on $12^{\text {th }}$ May 2008 at http:// www.conciseoxforddictionary/c0d 9

Fepuleai, S. M. (2007). Quality assurance of school education and training in Samoa, accessed on $2^{\text {nd }}$ March 2008 at http://www.apqn.org/events/ past/details/102/ present

Gerhart, J. (2006). Policy on standards, expectations and qualifications of academic staff, accessed on $18^{\text {th }}$ July 2008 at http://www.csu.edu.au /adminman/hum/ StandardsAcadStaffPolicy.doc

Geli de Ciurana, A. M., \& Filho, W. L. (2006). Education for sustainability in university studies: Experiences from a project involving European and Latin American universities, International Journal of Sustainability in Higher Education 1 (7) $1-34$, accessed on $15^{\text {th }}$ July 2008 at http://www.emeralinsight.com

Gibson, C. B., \& Cohen, S. G. (2003). Virtual Teams that Work : Creating Conditions for Virtual Team Effectiveness. San Francisco: Jossey-Bass.

Goodhew, P. (2007). Helping academic staff to be successful, Added Value Workshop, accessed on $15^{\text {th }}$ July 2008 at http://www.engsc.ac.uk/down loads/scholarart/ ee2008/w013-goodhew.pdf

Gerhard, H. S., \& Gördel, B. (2006). Quality Assurance in the German School System, European Educational Research Journal, 3, 5 196-209: http://dx.doi.org/

Getler, P., \&. Glewwe, P. (2002). Effects of public financing on educational input resources in teacher training institutions in Developing Countries: Evidence from Peru. Washington, DC: World Bank.

Ghobadian, A., Speller, S., \& Jones, M. (2005). Service quality concepts and models, International Journal of Quality \& Reliability Management, 9 (11) 43-66.

Kasozi, A.B.K. (2003). University education in Uganda: Challenges and opportunities for reform, Kampala: Fountain Publishers Ltd.

Kayongo, P. (2007). Financing and quality of education in institutions of higher learning, Journal of Bankers 2, 5, 79-89

Kothari, C.R. (2005). Research Methodology: Methods and Techniques ( $2^{\text {nd }}$ Ed), New Delhi: New Age International.

Lejeune, M. (2005). The Ugandan universities: The challenge of quality, Uganda Higher Education Review. Kampala: Ministry of Education and Sports.

Lewin, K. (1947). Frontiers in group dynamics 1, Human Relations 1, 5-41.

Lenz, R. T. (1998). Determinants of organizational performance: An interdisciplinary Review, Strategic Management Journal, 2, 131-54.

Malick, L., \& Grisay, A. (2000). The quality of education in developing countries: A review of some case studies and policy documents. Paris International Institute for Educational Planning. UNESCO.

Manyindo, S. (2008). Internal control and service quality at FFED. Makerere University Business School: Unpublished MBA Dissertation

Munroe-Blum, H. (2004). Universities at a Crossroads, Speech delivered to the Canadian Club of Montreal. Accessed on $25^{\text {th }}$ February 2008 at http://www.mcgill. ca/principal/s peeches/crossroads/ 
Mutula, S. M. (2002). University education in Kenya: current developments and future outlook, International Journal of Educational Management, 3, 16, accessed on $12^{\text {th }}$ May 2008 at http://www.emeraldinsight.com

Musaazi, J. C. S. (2005). Educational Planning: Principals, Tools and Applications in the Developing World. Kampala: Makerere University.

Sánchez, M. P. \& Elena, S. (2006). Intellectual capital in universities: Improving transparency and internal management, Journal of Intellectual Capital, 4, 7, accessed on $12^{\text {th }}$ May 2008 at http://www.emeraldinsight.com

Scott, P. (2004). The Case for Public Universities, accessed on $19^{\text {th }}$ February, 2008 at http://www.kingston.ac.uk/vc-office/

Tam Wai-Ming, F. (2008). The Management of Education Quality: Comparison of Competing Perspectives, accessed on $6^{\text {th }}$ March 2008 at http://sunzi1 .lib.hku.hk/ hkjo/view/33/3300

Waithanji-Ngware, M. \& Ndirangu, M. (2005). An improvement in instructional quality: can evaluation of teaching effectiveness make a difference? Quality Assurance in Education, 3, 13, accessed on $12^{\text {th }}$ May 2008 at http://www.emeraldinsight.com

Zeithaml, V. A., Parasuraman, A., \& Berry, L. L. (2004). Delivering Quality Service. New York: Free Press. 